\title{
Systems and other minimalism in Britain
}

Virginia Anderson

Reprinted (with updates and corrections) by permission of the Publishers from 'Systems and other Minimalism in Britain', Chapter 4 of The Ashgate Research Companion to Minimalist and Postminimalist Music, ed. Keith Potter, Kyle Gann, and Pwyll ap Siôn (Farnham, Surrey: Ashgate, 2013), pp. 87-106.

\section{Introduction}

In 1970, Gavin Bryars invited Steve Reich, who was in London, to play recordings of his recent compositions at a gathering that included many members of the Scratch Orchestra, the Promenade Theatre Orchestra, and the Portsmouth Sinfonia. Bryars shared a large house with Evan Parker in northwest London; Christopher Hobbs temporarily sublet part of the first floor. The composers decided to entertain Reich in Hobbs's room because it was biggest; Bryars brought his Revox tape recorder downstairs, as it was the best. Reich played Four Organs (1970), the first time it would have been heard in London. In return, Bryars played a recording of the William Tell Overture by the Portsmouth Sinfonia, an ensemble of arts students and faculty often known as the 'world's worst orchestra'. Michael Nyman remembers that 'the Anglo/American love-in was stretched to its limits' at this moment. ${ }^{1}$ Reich later hired several of these composers to play on his European tour of Drumming, but for Nyman, Reich failed to 'get' the Sinfonia. ${ }^{2}$

This meeting demonstrates that although American and British minimalists had a 'special relationship', they were not identical. Four Organs offers a parallel with the music that the British minimalists were writing, but while Four Organs used electronic organs, the composer-performers in the Promenade Theatre Orchestra played cheap, unamplified reed organs. Whilst Reich had developed a 'gradual process', British composers had been writing a process music called 'Machines' and had begun to use the term 'systems', borrowed from the visual arts. British composers leavened their 'systems' processes, like their experimental indeterminacy, with humour, musical and non-musical reference, and unusual instrumentation. Finally, there were non-minimalist fringe activities such as the Portsmouth Sinfonia. Since 'systems' minimalism encompasses a variety of styles and processes, I will discuss elements of minimalism in British experimental indeterminacy, before moving through static (or what is often called 'minimal') minimalism, to more recent developments in random systems music and strict systems processes.

\section{Experimental relations}

Just as American minimalism emerged from the philosophical and technical precepts of American experimental music, British systems arose from British experimental methods and thought, which centred on the figure of Cornelius Cardew (1936-81). He had worked in the late fifties with Stockhausen on Carré (1959-60), and one of the features he liked in realizing this work was the idea of "sounds at peace", which last and last and do not change ...' Cardew fantasized about extending their duration further: 'while

\footnotetext{
${ }^{1}$ Michael Nyman, Experimental Music: Cage and Beyond (Cambridge, 1999 [1974]), p. xvii. Nyman writes that this happened in 1971, but Hobbs lived in Bryars's house in Brondesbury Villas only for a few months around May 1970. Hugh Shrapnel and Bryn Harris (email to author, 27 December 2011), who also attended, again give the year 1970.

${ }^{2}$ Nyman, email to author, 27 December 2011.
} 
composing, I would often write "a sound" and gaze out of the window at the summer afternoon gardens "listening" to it for 10 to 20 minutes, and not just the 12" or whatever it might be that was actually audible in the concert hall'. ${ }^{3}$ Cardew also wrote of hearing a recording of a performance by La Monte Young, Marian Zazeela, Tony Conrad, and John Cale (who had brought the tape to England): 'The one sound ... was actually very beautiful, and got progressively more beautiful through the half-hour that the tape lasted'. ${ }^{4}$

British experimental composition and performance in the 1960s used elements of repetition, non-developmental processes, and drones. Some of this music may show synchronicity with - rather than an emulation of - the American movement (the free improvisation group AMM had a minimalist, 'laminal' sound before Cardew joined); other pieces adapted American minimalist processes. According to some Scratch Orchestra members, some paragraphs from Cardew's The Great Learning (1968-71) were meant as tributes to American minimalists. ${ }^{5}$ Paragraph 2 is, ostensibly, a reference to Terry Riley, as it consists of repeated motivic cells. If so, it was a timely homage: Christopher Hobbs mounted the English premiere of In $C$ in 1968, the year before Paragraph 2 was premiered. ${ }^{6}$ By June 1969, In C was listed in the Draft Constitution of the Scratch Orchestra as a composition 'performable by the orchestra'. ${ }^{7}$ It was also used to represent the inner ear in their Fantastic Voyage concert 'Pilgrimage from Scattered Points on the Surface of the Body to the Heart, the Stomach and the Inner Ear' at the Queen Elizabeth Hall on 23 November 1970, because it was 'based on a predominantly auditory experience and $\ldots$ is mesmeric, hypnotic'. ${ }^{8}$ Paragraph 7 is reputed to honour Young, perhaps referring to the drone recording that Cale played for Cardew. Paragraph 7 uses a 'network' system of sung pitches held for the length of a breath; performers move through its material at their own pace like In $C .{ }^{9}$ Because singers choose each subsequent pitch from those they can hear (with a reduction in available pitches), Paragraph 7 also exhibits a similar physical decay process to Reich's Pendulum Music (1968), in which microphones, swung in front of speakers, slowly achieve a resting state.

Other music created by British experimentalists during this time could also be classified as minimal. Early pieces by Howard Skempton (b. 1947) and early Machine systems by John White (b. 1936) are written largely, or entirely, in common-practice notation; these will be examined later. There are other works that, whilst using indeterminacy and text notation (instruction, or 'verbal', compositions), are indicative of British minimalism, just as Pendulum Music or some of Young's set of Compositions are part of American minimalism. Michael Parsons' (b. 1938) Mindfulness Occupied with the Body, for singers, percussion and drone instruments (1970), is a text composition based on Buddhist chant that anchored the already-mentioned 1970 Scratch Orchestra Pilgrimage concert. Hobbs's text piece Island Game Rite (1969) is perhaps the most 'systemic' piece among the early Scratch Orchestra collection, Nature Study Notes. This composition has a 'readymade' found system, as it uses the permutations of actions in a newspaper pop

\footnotetext{
${ }^{3}$ Cornelius Cardew, 'Report on Stockhausen's Carre, The Musical Times, 102/1424 (1961), p. 622.

${ }^{4}$ Cardew, 'One Sound: La Monte Young', The Musical Times, 107/1485 (1966), p. 960.

${ }^{5}$ Cornelius Cardew, The Great Learning (London, 1971). The Scratch Orchestra was an ensemble founded by Cardew, Howard Skempton, and Michael Parsons in 1969.

${ }^{6}$ Christopher Hobbs, conversation with author, 23 December 2011. November 2015: Date of In C premiere corrected to 1968. Hobbs directed it for the Sounds of Discovery Concert, 18 May 1968, with Young's Death Chant.

${ }^{7}$ Cardew, 'A Scratch Orchestra: Draft Constitution', The Musical Times, 110/1516 (1969), p. 619.

${ }^{8}$ Scratch Orchestra internal letter, July 1970.

${ }^{9}$ Michael Nyman, Experimental Music, p. 125.
} 
morality game to determine improvised responses. Hobbs's One Note 1966 is also a text instruction piece, but it directs the players to produce what is known informally as 'minimal minimalism'.

\section{'Minimal' Minimalism}

Dave Smith considers Hobbs's One Note 1966 to be the first English minimal composition. ${ }^{10}$ Hobbs was then only fifteen years old and his piece was influenced by La Monte Young. He originally wrote One Note 1966 in common-practice notation for a small ensemble of wind and strings playing $\mathrm{c}^{1}$ for fixed durations, and thus, in this early version, resembles Young's Trio for Strings (1958). ${ }^{11}$ In 1967, when Hobbs began his study at the Royal Academy of Music, Cardew, his composition teacher, suggested that Hobbs re-write the piece in text notation. ${ }^{12}$ This new version differs from the original notated score in the same way that Young's Composition 1960 \#10 (which contains the instruction, 'Draw a straight line and follow it') differs from Composition 1960 \#7 (b and $\mathrm{f \#}{ }^{1}$ on a treble clef staff, with the words, 'to be held for a long time'). ${ }^{13}$

Cardew was interested at this time in designing text pieces that were 'fool-proof' against loose, free-for-all performances, and Hobbs took such care and attention in One Note 1966. Hobbs includes such safeguards as the prohibition of mechanical bowing and breathing devices (to prevent an eternal performance), and a prohibition against total silence (when a silence is perceived, the performer must fill the gap with a note). He limits the instrumentation to bowed strings and wind instruments of any number and combination. The players still only play one note, but they choose the note that they play. Performers could also choose the length of their notes (except for 'staccato'), whilst silences should not be more than twice the duration of the performer's longest note. Players must sit around the hall antiphonally and play as quietly as possible, leaving silences between their notes. Finally, Hobbs indicated a total length: 'The piece must last a long time', evoking the instruction in Composition 1960 \#7.

Howard Skempton, however, is the British composer most closely associated with 'minimal' minimalism. Skempton wrote his first minimal composition, A Humming Song, in April 1967, just before he began to study with Cardew. Written for a solo pianist who sustains certain notes by humming, A Humming Song is fixed in common-practice notation; it presents permutations of a limited set of pitches that Skempton chose through chance procedures. The performer must also hum certain pitches to sustain them, which, as Michael Parsons has observed, needs skill and control to accomplish well. ${ }^{14}$ Parsons considered this early piece to embody Skempton's lifelong approach to limited materials.

There is thus already in this early piece a finely balanced relationship between chance and intuitive selection. The method of composition gives the music a rather loose and 'timeless'

\footnotetext{
${ }^{10}$ Dave Smith, email to author, 2 July 2011.

${ }^{11}$ The use of one note is actually closer to the seventh of Elliott Carter's Eight Etudes and a Fantasy (1947-50), which sets a single $g^{1}$ contrapuntally for woodwind instruments, but Hobbs was unaware of this piece at the time. November 2015: The published version removed the indication for register in Hobbs (C\#, one-half step above middle C) and Carter ( $\mathrm{G}$ above middle $\mathrm{C})$. In both works, the single pitch — without octaves — is important to their identity.

${ }^{12}$ Experimental Music Catalogue, Verbal Anthology (London, 1972), p. 27. November 2015: changed 'work' to 'piece' to avoid confusion with the common-practice 'work-concept'. This occurs throughout this version, with 'composition' and 'score' also used to replace 'work'.

${ }^{13}$ La Monte Young and Jackson MacLow, eds., An Anthology of Chance Operations (New York, 1963).

${ }^{14}$ Michael Parsons, ‘The Music of Howard Skempton', Contact 21 (1980), p. 12.
} 
quality, drawing attention to the unique sonority of each note or chord as it occurs, rather than to the structure of the piece as a whole. ${ }^{15}$

A Humming Song, plus Snowpiece and September Song (both for piano and written in 1968), began one strand of Skempton's compositional style that existed until the 1990s. The pieces in this strand are economical and balanced; they have clear, almost architectural proportions, perceptible even when a piece does not have bar lines, or when - as in Snowpiece - the durations are given in seconds rather than note values. Skempton's other strand consists of what might be called 'sweet minimalism', in which simple sentimental melodies are set economically. Skempton called these 'occasional' pieces, as they were often written for birthdays and other events. ${ }^{16}$ One for Molly for piano (1972), for example, was written for Michael Nyman's daughter's first birthday. Some of these fragile, quiet compositions are 'minimal' only in the sense that they are not complex; they have the narrative structure of 'normal' miniatures. Others are 'experimental' in some other way, as in Waltz for solo piano (1970), described by Nyman as 'even more devoid of drama and surprise than Satie's [tonality]', ${ }^{17}$ due to its stubborn adherence to $\mathrm{C}$ major. In Waltr, Skempton applies a sectional permutation system (A, B, A, A, A; C, D, B, D C, etc.) to simple, short waltz-like figures. This repetition extends the duration of Waltz to around twelve minutes and prolongs the empty cheeriness of the musical content. Skempton told Nyman that he considered form to be central to composition:

The composer is concerned with communicating the form, and concerned with sound as the most powerful means of communicating the form. The form is the single idea motivating the piece; without this concentration of attention there is no unity. And without economy there is no power; and without self-control there is nothing. ${ }^{18}$

Skempton describes his own work here, but other British minimalists focus on form and unity just as strongly. Most of these composers exhibit just as much self-control as Skempton, no matter whether their processes are 'minimal' minimalism, random process or numerical systems.

\section{Random process minimalism}

Gradual process repetition of the type used by Reich, Glass, and Riley is rare in British minimalism. Hobbs's Working Notes, for three toy pianos and reed organ (1969), most closely resembles contemporary process music by Glass and Reich, as it presents melodic figures that are transformed by means of a gradual process. Bell Set No. 1 (1971) by Michael Nyman (b. 1944) presents a simple expansion of opening and closing durations of a motivic fragment, much like Four Organs does. ${ }^{19}$ But here we can see a difference between early 1970s New York minimalism and contemporary British systems music: British composers were not concerned with articulating the pulse to heighten the hypnotic effect of the process. Working Notes has a typical New York drive, as the system uses regular quaver figures, but Hobbs does not add anything more to help it along: the material itself provides its propulsion. Despite having a system resembling Four Organs, Bell Set No. 1 does not have Four Organs' propulsive drive because, as ap Siôn notes, 'Four Organs also includes a "metronomic" fifth part for maracas', while Bell Set No. 1 has no

\footnotetext{
${ }^{15}$ Michael Parsons, 'The Music of Howard Skempton', p. 12.

${ }^{16}$ Howard Skempton, interview by the author, London, 12 May 1983.

${ }^{17}$ Nyman, Experimental Music, p. 168.

${ }^{18}$ Howard Skempton, quoted in Michael Nyman, Experimental Music, p. 167.

${ }^{19}$ Nyman had interviewed Reich in 1970 and again in 1971 (Pwyll ap Siôn, The Music of Michael Nyman: Texts, Contexts, and Intertexts (Aldershot: Ashgate, 2007), p. 39), proclaiming a pre-release pressing of Four Organs to be 'a new classical music of unprecedented quality' (Nyman, 'Uncommercial', The New Statesman, 20 August 1971, p. 248).
} 
prescribed pulse instrument. ${ }^{20}$ British random process music differs in other respects from American minimalism, including its use of existing sources, references, and affect.

Although 'systems' was used as a catch-all term for repetitive music in the USA in the 1980s (this almost certainly due to Nyman's popularity), in Britain in the early 1970s it referred to a specific family of compositional techniques. ${ }^{21}$ At first, systems composers used random means to generate their processes; later, they used fixed number permutations or series. Although random processes would seem to evoke a kind of Cagean chance experimentalism and fixed number systems evoke a kind of serial rigour, in practice, random and fixed number systems are not so different. Whatever their origin, systems usually generate a note-to-note (or bar-to-bar) musical process. For example, John White's Carillons for trombone and piano (1964) uses numbers obtained from dartboard throws, resulting in a repetitive process.

White's Machine composition series, beginning with Macbine for cello and tuba (1968), represent the earliest form of British random-process minimalism. White originally used chess moves, dartboard throws, and random number tables to generate his processes. The system for the tuba is generated by knight's moves across a number square, ${ }^{22}$ whilst the cello has a separate system applied to the intervals and use of pizzicato. ${ }^{23}$ White intended that his Machine pieces would be pleasant: ' $[\mathrm{t}]$ he sounds tend towards a sort of ragged consonance, the procedures usually involve much repetition with changes happening almost imperceptibly over large spans of time, and the atmosphere is usually pretty calm and unruffled, however fast the pace of the music'. ${ }^{24}$

White's description of his Machine music as 'calm and unruffled' is typical of his approach to music. White also wrote that his P.T. Machine for mixed ensemble (1969) was 'the result in sound of reading random number tables in the same way as one would read a thriller'. ${ }^{25}$ Given the abstract nature of modern music at the time, White's claim that music communicates a cool demeanour (and his inference that random numbers are exciting) is significant.

In the first version of White's Drinking and Hooting Machine, for four performers playing bottles (1970), performers choose numbers between 1 and 99 from L.C.H. Tippett's book Random Sampling Numbers. ${ }^{26}$ White and Hobbs later preferred to consult the newer Tables of Random Permutations, edited by Lincoln E. Moses and Robert Oakford. ${ }^{27}$ Their enthusiasm for this document, combined with their penchant for puns, resulted Hobbs's percussion piece Lincoln E. Moses Comes Down from the Mountain (1973). A standard telephone directory provided another method for obtaining random numbers,

\footnotetext{
${ }^{20}$ Pwyll ap Siôn, The Music of Michael Nyman, p. 42.

21 'Systems' was used for British minimalist processes at least as early as 1971, but I first heard of 'systems' when I began researching them in Britain in 1982. The term became known in America sometime during the next few years perhaps after the release of Nyman's soundtrack for The Draughtsman's Contract in 1982. In 1993, its 'fashion' as a general term had waned. Jonathan W. Bernard wrote, 'The label, after all, has stuck in a way that such terms as "phaseshifting", "repetitive", "systems" or "systemic", "process", or "trance" music never did' (Bernard, "The Minimalist Aesthetic in the Plastic Arts and Music' Perspectives of New Music, 31/1 (1993), p. 87).

${ }^{22}$ Dave Smith, Annotated list of compositions by John White (unpublished).

${ }^{23}$ Christopher Hobbs, conversation with the author, 22 December 2011.

${ }^{24}$ John White, quoted in Michael Nyman, 'Believe It or Not, Melody Rides Again', Music and Musicians, 20/2 (1971), p. 27.

${ }^{25}$ John White, in programme note for the premiere of P.T. Machine by Intermodulation, Queen Elizabeth Hall, 18 October 1970.

${ }^{26}$ L.C.H. Tippett, Random Sampling Numbers (Cambridge: Cambridge University Press, 1927).

${ }^{27}$ Lincoln E. Moses and Robert Oakford (eds.), Tables of Random Permutations (California, Stanford University Press, 1963).
} 
using the last one, two, or three digits from a column on a freely opened page as needed. This method, being more accessible to performers, appeared in the second version of Drinking and Hooting Machine, for any number of performers. ${ }^{28}$ For the final version, also for any number of performers, White specified numbers from 1-10, to indicate the number of repetitions of pitches and their alterations - 'sip', 'swig', 'gulp', 'as is — - on bottles 'of a favoured drink'. ${ }^{29}$ The bottles are blown across to produce the pitches, which, as the contents of the bottle are drunk, lower until the bottle is empty. This version appeared on the Obscure album Machine Music, the largest recorded collection of these early systems pieces. ${ }^{30}$ White has created other versions since, using an adaptation of change-ringing permutations. ${ }^{31}$

Like Drinking and Hooting Machine, other machines also reflect day-to-day activities, such as common household objects (Newspaper Reading Machine), toy instruments (Swanee Machine, for swanee whistles, Melodica Machine, and Jew's Harp Machine (all 1970)). Autumn Countdown Machine, for groups matching two low-pitched instruments with a percussionist playing a bell metronome (1971), leavens the slow, trudging melodic lines of the low instruments with the then state-of-the-art bell metronomes, in 'an almost toytown simplicity'. ${ }^{32}$ Other process minimalism of the time includes Hugh Shrapnel's (b. 1947) Cantation I for piano (1970), in which the left and right hand alternatively add musical material. Gavin Bryars used networking systems between players and other physical effects to achieve structure, thus moving from the emphasis on repetition to other musical features. Another structural gambit, featured in the Promenade Theatre Orchestra, was to repurpose pre-existing material to make 'readymades'.

\section{Found or 'trouvé' systems and 'readymades'}

White founded the Promenade Theatre Orchestra (more often known as the PTO, a play on the indication 'please turn over') in 1969, partly to play compositions by its members and partly to while away Sunday afternoons before the pubs opened. The PTO, which met first at the New Arts Laboratory in London and then at White's flat in Wimbledon, fluctuated in membership (Brian Dennis took part in some rehearsals), but settled into a quartet of White, Hobbs, Alec Hill (1941-2013) and Hugh Shrapnel. PTO's activities, instrumentation, musical content, and advertising all reflect White's personality: a combination of Edwardian gentlemen's club bonhomie, schoolboy 'jolly japes', plus Satiean puckishness and irony. ${ }^{33}$ Members brought in compositions each week to be trialled by the group, who played reed organs and toy pianos, plus percussion and their own secondary instruments (Shrapnel on oboe, Hill on clarinets, White on tuba and trombone, Hobbs on bassoon). Successful pieces were added to the PTO repertoire to

\footnotetext{
${ }^{28}$ This version was published in Brian Dennis, Projects in Sound (London, 1975), pp. 45-6. This book is intended for school children, so the performers are limited to a 'flavoured' (rather than 'favoured') drink, with orange juice suggested.

${ }^{29}$ White, Drinking and Hooting Machine, in Scratch Orchestra, Scratch Anthology of Compositions (London, 1971), p. 6. White was unsure whether this Experimental Music Catalogue version was made using random numbers, but thought that if it had been, he would have obtained the numbers from Tippett; Dave Smith, in his catalogue of White's compositions (unpublished), notes that it uses 'smaller random numbers than the first version'. Smith labels this version 'official'.

${ }^{30}$ John White and Gavin Bryars, Machine Music (Obscure OBS-8, 1978).

${ }^{31}$ John White, personal correspondence, 7 November 2007.

32 Stephen Walsh, review, The Times, October 1971, quoted in Smith, Annotated List of Compositions by John White. György Ligeti's piece for 100 metronomes, Poème Symphonique (1962), is much simpler, and articulates only the process that begins when a mechanical metronome is activated and then winds down.

${ }^{33}$ During one after-rehearsal drinking session, the members held a PTO 'initiation'. Each member had to prove their 'toughness' by downing a Snowball, a sweet cocktail often considered a 'lady's drink' (Hobbs, in conversation with the author, 21 December 2011).
} 
be performed. Musical processes included White's random Machines, other systems, and the musical 'readymade'.

Hobbs specialized in the musical 'readymade', modelled on Marcel Duchamp's visual art 'readymade'. ${ }^{34}$ In a Duchampian readymade, an everyday object ('found' object, or objet trowve) is presented as the artwork, usually with little or no alteration other than its presentation as art in a gallery or exhibition. Duchamp's Fountain (1917), a urinal signed with the pseudonym ' $\mathrm{R}$. Mutt', is the best known of these, Other musical readymades combine existing material in new ways, analogous to Duchamp's earlier Bicycle Wheel (1913), a construction in which a bicycle wheel is attached upside-down by its fork to the seat of an unrelated object, a wooden stool.

Hobbs used two approaches for his 'readymades'. The first approach takes 'readymade' materials (an existing score or a number of scores) and puts them through a system or other process. His Arnold/Wolf-Ferrari Orchestra Book for orchestra (1969-70) is, according to Hobbs, 'a chance-determined palimpsest of existing orchestral scores', systematizing approximately 250 particles from the music of ninety composers. ${ }^{35}$ The Remorseless Lamb for two pianos (1969) randomizes a piano duet arrangement of Bach's 'Sheep May Safely Graze', changing the order of the original bars and of each part's left and right hands. The piece remains recognizable, but it loses the narrative impetus of the original. A later piece, Timpani Studies for percussion (1973) slows down timpani exercises until new rhythmic patterns appear. ${ }^{36}$

The other approach is the 'found system', in which new musical material is organized according to a readymade structure. As mentioned before, Island Game Rite, in using a newspaper morality quiz, is an early example of the 'found system'. Note-for-note found systems processes include change ringing, or campanology, which Alec Hill used in PTO pieces. His Large Change Machine uses the Plain Bob hunt; the Small Change Machine also uses a plain hunt, applied to all four parts. ${ }^{37}$ Bell-ringing courses offer a different order than simple permutation, due to the tendency for certain bells to follow (or 'hunt') other bells from left to right in the process.

Sources could be surprising, and even possibly misleading. Hobbs's best known 'found' systems piece for the PTO, Aran (1972), the title of which seems to evoke the romance of the Irish islands, was a knitting pattern for an Aran sweater that Hobbs discovered in a magazine. Aran, like much of White's PTO machines and piano duets by John Lewis and Dave Smith, applies the process to bars of musical material rather than to each note. The knitting process is divided between four parts (equivalent to four rows of knitting), having four different types of musical material (types of stitches), in groups of seven bars followed by groups of twelve.

\footnotetext{
${ }^{34}$ Pwyll ap Siôn writes that Bryars also used 'readymades' to describe his own music, citing the 'found' recording used in his piece Jesus' Blood Never Failed Me Yet (1971) (ap Siôn, The Music of Michael Nyman, p. 49). Bryars wrote that 'it was Hobbs who introduced into the PTO the idea of the musical readymade' (Bryars, 'Satie and the British', Contact 25 (1982), p. 11).

35 'Christopher Hobbs: Compositions', EMC Composers < http://www.experimentalmusic.co.uk/ Experimental_Music_Catalogue/EMC_Composers_files/> (accessed 22 December 2011); Peter West and Peter Evans, 'Interview with Christopher Hobbs', Contact 2 (1971), p. 19. This piece has never been performed.

${ }^{36}$ Hobbs favoured slowing down readymade material (for instance, the bagpipe skirls in McCrimmon Will Never Return) until the original rhythm and melody is unrecognizable. Later he slowed down proprietary sample percussion loops on electronic digital keyboards in a similar way, as in some of the pieces in 17 One-Minute Pieces for Bass Clarinet and Casio MT-750 (1992).

${ }^{37}$ Brian Dennis, 'Repetitive and Systemic Music', The Musical Times, 115/1582 (1974), p. 1037.
} 

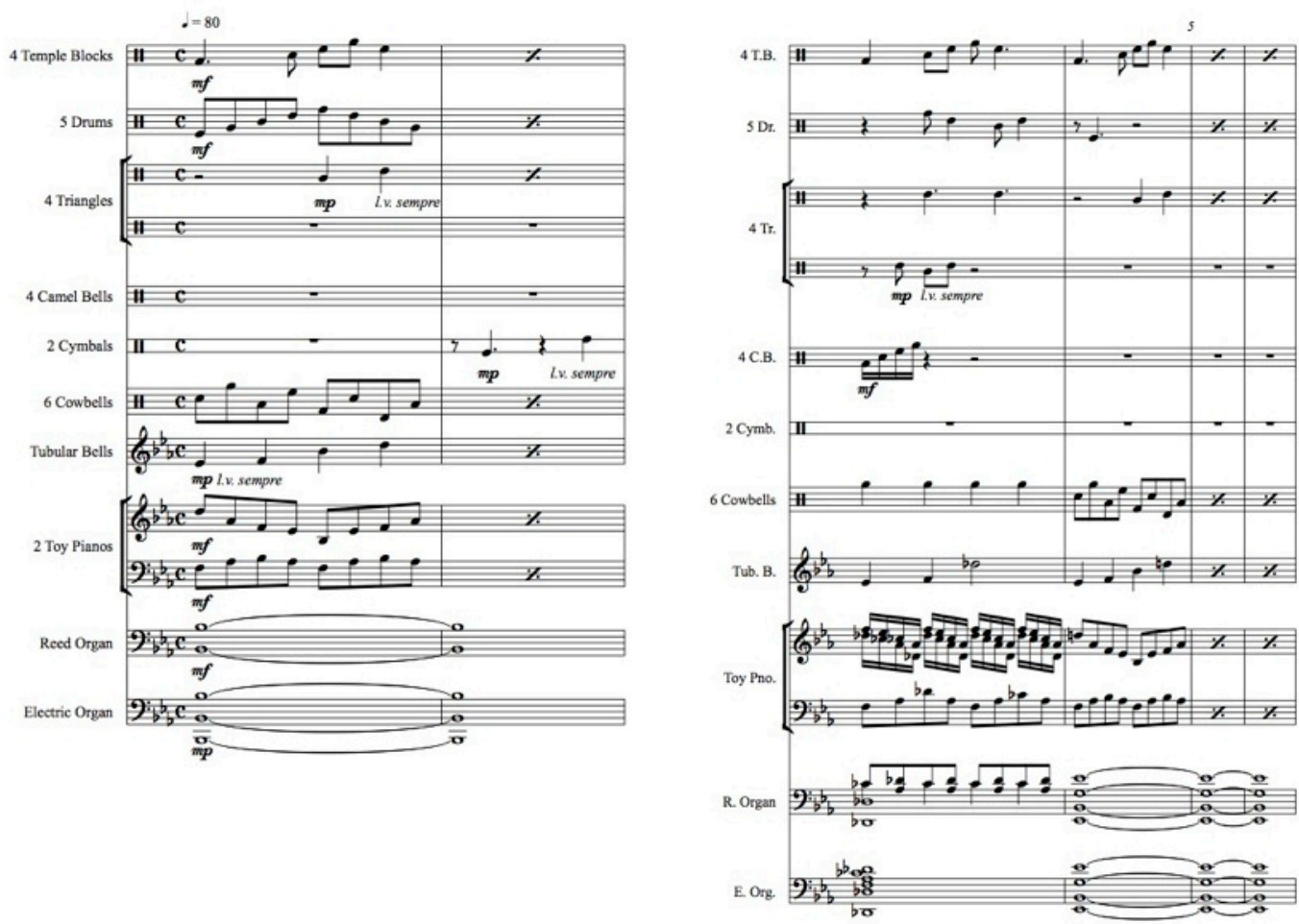

Ex. 4.1: Christopher Hobbs, Aran (bb. 1-6)

Aran ends with an antiphonal two-bar repetition of the fourth type of material (which could indicate a cable stitch or other decorative feature). Few of Hobbs's compositional sketches have survived from this period and the exact knitting pattern has not been recovered.

\section{Systems with blurred edges}

Within the systems 'family', labels used by the PTO composers have been somewhat vague. What makes a borrowed system a readymade and not a transcription, arrangement, or setting? Are bar-for-bar systems as 'systemic' as note-for-note ones? Alec Hill's campanological pieces could be transcriptions from church bells to toy pianos (with some added material) if change ringing is considered to be music, but they are also note-for-note systems. ${ }^{38}$ Hugh Shrapnel's Carolina Moon, for two toy pianos and two reed organs (1971), is an arrangement of an Edwardian piece and, despite its repetitive structure, is not systemic. Bryars' Jesus' Blood Never Failed Me Yet sets the source song for orchestra. The companion piece to Aran, Hobbs's McCrimmon Will Never Return, for four reed organs (1972), is a simultaneous presentation of variant versions of the piobaireachd (bagpipe) piece. McCrimmon is simultaneously a transcription and a readymade, but it is not systemic. The McCrimmon structure, however, influenced Hobbs's later Sudoku systems (from 2005), in which four sudoku grids overlaid on each other combine to determine the note-to-note progression of each piece.

Hobbs uses the text of Samuel Beckett's novel Watt as both a readymade process and normal text setting. The novel is 'an account of the grotesque and improbable

\footnotetext{
${ }^{38}$ My student Sonja Ashbury, who did fieldwork with local bell-ringing groups for a class in 2008, found a general consensus that campanology is considered a social activity rather than musical performance.
} 
adventures of a fantastically logical Irish servant and his master'. ${ }^{39}$ Hobbs calls Watt a 'systemic' novel, because a number of passages contain groups of items, arranged in permutation. For a concert at the New Arts Laboratory in London in 1969, he set passages that presented systemic features for four voices (Hobbs, Michael Parsons, Howard Skempton, and Shrapnel). One particularly relevant passage uses a permutation of vocal sounds:

\begin{abstract}
Now these voices, sometimes they sang only, and sometimes they cried only, and sometimes they stated only, and sometimes they murmured only, and sometimes they sang and cried, and sometimes they sang and stated, and sometimes they sang and murmured, and sometimes they cried and stated, and sometimes they cried and murmured, and sometimes they stated and murmured, and sometimes they sang and cried and stated, and sometimes they sang and cried and murmured, and sometimes they cried and stated and murmured, and sometimes they sang and cried and stated and murmured, all together, at the same time, as now, to mention only these four kinds of voices, for there were others. And sometimes Watt understood all, and sometimes he understood much, and sometimes he understood little, and sometimes he understood nothing, as now. ${ }^{40}$
\end{abstract}

This permutation of four types of vocal delivery produces the system of separate bars of a single type, followed by pairs, then trios, and ending with all four types of voice: $1 ; 2 ; 3$; $4 ; 1,2 ; 1,3 ; 1,4 ; 2,3 ; 2,4 ; 3,4 ; 1,2,3 ; 1,2,4 ; 2,3,4 ; 1,2,3$, 4. Hobbs wrote that, 'Watt presents simple systems - in fact, they're permutations — a system needn't be as clearly finite as those in Watt. ${ }^{41}$ Nevertheless, occurring so early in the development of repetitive systems, the Watt concert was a significant event. It should therefore be important to the study of Beckett and modern music, but it has so far escaped the notice of music scholarship on Beckett. ${ }^{42}$

Much of the music discussed thus far is minimal or repetitive rather than systemic. Brian Dennis attempted to differentiate between the two:

It is difficult to determine precisely at what point repetitive music becomes 'systemic'. If we take Chris Hobbs's definition of the latter as 'music in which the structure and note-to-note procedure are dictated by a numerically expressible construct', some of the pieces so far discussed come close to this. Chance and individual choice are replaced by precise numbers of repeats or the sections themselves are numerically derived. The idea of number against number is also frequently found..$^{43}$

Here, Hobbs defines the systems process in which he was interested after the PTO broke up, when he and White continued as the Hobbs-White Duo. ${ }^{44}$ In its first year, the Hobbs-White Duo performed primarily on percussion, creating these 'strict' systems.

\title{
Strict systems
}

British systems composers did not have to look far for another model for strict systems: they found it at work. Because of the conservatism of British musical life, few

\footnotetext{
${ }^{39}$ Detail on jacket cover of Samuel Beckett's Watt (New York: Grove Press, 1959).

${ }^{40}$ Beckett, Watt, p. 29.

${ }^{41}$ Hobbs, letter to the author, 31 October 1983.

${ }^{42}$ This scholarship includes Daniel Albright, in Beckett and Aesthetics (Cambridge, 2001) and Andrea Oppo, in Philosophical Aesthetics and Samuel Beckett (Bern, 2008). Catherine Laws names Bryars, Parsons and Hobbs amongst fortynine composers who have used Beckett (in Laws, Headaches Among the Overtones: Music in Beckett/Beckett in Music (Amsterdam: Rodopi, 2013), p. 231, without comment, focusing instead on Morton Feldman, Richard Barrett (a British composer of the 'New Complexity' School), and György Kurtág.

${ }^{43}$ Dennis, 'Repetitive and Systemic Music', p. 1037.

${ }^{44}$ The PTO broke up along political lines in 1973, as Shrapnel and Hill became involved in the radical politics of the late Scratch Orchestra.
} 
experimental composers could find positions in music colleges and universities. ${ }^{45}$ Instead, these composers mainly worked in arts and drama schools, at least until the late 1970s, when Gavin Bryars founded a music department at Leicester Polytechnic. Portsmouth College of Art was such an arts school, and the systems artist Jeffrey Steele was its department head. Michael Parsons and Bryars taught music as part of a complementary studies programme at Portsmouth (and helped to develop the Portsmouth Sinfonia): Hobbs, White, and Skempton were guest lecturers. The composers and artists soon found an affinity between the arts in their use of numbers.

British systems art took its influences from Russian Constructivist art, Bauhaus and de Stijl. ${ }^{46}$ As early as 1960, British Constructivist artists used number systems. For instance, in Anthony Hill's Prime Rhythms (1960, plastic 31x29 cms), prime numbers determine the placement of parallel lines within the composition. In 1969, Steele and Malcolm Hughes cofounded the British systems art group, which they launched that year with a manifesto and an exhibition in Finland. ${ }^{47}$ The systems art group not only included Steele and Hughes, but also Michael Kidner, Peter Lowe, David Saunders, Jean Spencer, and later Keith Richardson-Jones. Their work presented strict, non-objective and nonfigurative lines and shapes arranged according to mathematical principles. These principles usually resulted in linear compositions, such as Steele's Series Sg... (1973): paintings that were 'designed to exhibit the maximum range of aesthetic possibilities of diagonal symmetry’. ${ }^{48}$

Systems artists and composers exhibited and performed in the same venues. The Lucy Milton Gallery, which opened in Notting Hill, London in 1971, became the primary venue for systems and constructivist art. It also held concerts of systems music, including those by the duos of Dave Smith and John Lewis (both b. 1949), Howard Skempton and Michael Parsons, and the Hobbs-White Duo. These composers must have felt an immediate parallel between systems art and the minimalist music they already knew. White famously told Nyman in January 1971 that 'System and sentimentality are the SS of my Reich', perhaps the first reference to musical systems in print. ${ }^{49}$ Hobbs considered systemic processes to be analogous to 'found' systems; having generated the system himself, he could apply systems art principles to his own music. ${ }^{50}$ White also used strict systems as analogues to his random Machine systems.

Instrumentation in strict systems was limited for practical and aesthetic reasons. The Lucy Milton Gallery was tiny; it had no piano. Of the four works Smith premiered at the gallery between 1973-75, ${ }^{51}$ the biggest ensemble was five performers and a conductor. Experimental music had also been played in galleries, theatre foyers, and other venues that were not furnished for music performance (hence the PTO's toy pianos and reed organs), so this was not a new limitation. But strict systems demanded something less

\footnotetext{
${ }^{45}$ Cornelius Cardew taught composition part-time at the Royal Academy of Music from 1967 to the early 1970s; Brian Dennis taught composition and music education at Royal Holloway and Bedford New College, (now Royal Holloway College, University of London), in Egham, Surrey.

${ }^{46}$ Michael Parsons, 'Systems in Art and Music', The Musical Times, 117/1604 (1976), p. 815.

${ }^{47}$ Alan Fowler, Constructivist Art in Britain 1913-2005 (PhD thesis, Southampton University, 2006).

${ }^{48}$ Jeffrey Steele, 'Series SG....., explanatory text to the works.

${ }^{49}$ John White, quoted in Michael Nyman, 'Believe It or Not, Melody Rides Again', Music and Musicians, 20/2 (1971), p. 28.

${ }^{50}$ Christopher Hobbs, in conversation with the author, 18 December 2011.

51 'Dave Smith', EMC Composers, <http://www.users.waitrose.com/ chobbs/smithcomp.html> (accessed 19 December 2011).
} 
'colourful' than the jolly toys of the Scratch Orchestra and the PTO. Just as systems artists tended to limit themselves to black and white lines or blocks (at most grey tones or subtle pastels), Parsons, Skempton, White, and Hobbs used unpitched percussion to present strict musical systems. The systems artists restricted their visual palette to distance themselves from op art and its 'hypnotic' affect, ${ }^{52}$ a concern that was shared, it seems, by composers. Although Keith Potter has distanced Steve Reich (though not Philip Glass) from op art, ${ }^{53}$ Parsons has distinguished systems composition from American minimalism, using an analogy between systems and op art:

English systems art, with its emphasis on clear structure, is distinct from op art (which exhibits some systemic characteristics in degenerate form) in the same way that the percussion pieces of Hobbs and White differ from the music of Reich and Glass. English experimental composers are generally more interested in a structured sense of time, with clear divisions. Repetition is used not for its psychoacoustic effects, but as a ground for the creation of perceptible oppositions; because, in Kenneth Martin's words, 'we perceive change most readily within a restricted field of similarity'. ${ }^{54}$

Strict systems pieces for percussion are much like Reich's Four Organs in that they use durational patterns and shifting entries. Because of their restricted instrumentation and lack of articulated pulse, however, British strict systems are not experienced in the same way as Four Organs, Working Notes, or Bell Set No. 1. At times, the composers of strict systems seem to go to great lengths to destroy the physical and psychological sensations of a gradual process. White, in Photo-Finish Machine for two sets of four temple blocks (1972), from the Hobbs-White Percussion Anthology — a collection of strict systems pieces by the duo ${ }^{55}$ - systematizes durations of rests in such a way that the semiquaver-crotchet motive that appears throughout almost seems to be played at will, or at least with rubato. ${ }^{56}$ Systems present a 'cool' affect, so performers tend to play serenely and with little emotion. The music process is not 'physicalized' in the same way as most American process music, either for the listeners or performers.

One of the earliest strict systems piece, Christopher Hobbs's Number Piece 1 (197273), written contemporaneously with White's first strict systems, presents a clear numerical system as an alternation of wood blocks and cymbals rung at increasing and decreasing intervals of time. Hobbs wanted the process to be heard:

This was an attempt to produce the same effect aurally as a systemic artwork would produce graphically. The listener is aware that a system is unfolding, and it is fairly obvious how it works, even though such awareness may be confined to the beginning and ending of the piece. $^{57}$

Fig. 4.1 shows Hobbs's reconstruction of a graphic representation of the system, which preceded a traditionally notated performance score. In this graphic representation, the bracketed numbers above the note heads $(10,10,10$, etc., followed in system three by 11 ,

\footnotetext{
${ }^{52}$ Within the restrictions of the rules of systems art and op art, the contrasts can be striking, even in the work of a single artist. In the 1980s, Richardson-Jones was using the muted tonal processes consistent with systems art in a series of paintings (Series C Coincident Multiple Arrays). However, Richardson-Jones's op art from the 1960s, with its primary and secondary 'pop art' colour scheme and busy composition, contrasted greatly with his more recent, cooler, work of the 1980s.

${ }^{53}$ Keith Potter, Four Musical Minimalists: La Monte Young, Terry Riley, Steve Reich, Philip Glass (Cambridge, 2002), p. 11-12.

${ }^{54}$ Parsons, 'Systems in Art and Music', p. 816.

${ }^{55}$ Christopher Hobbs and John White, Hobbs-White Percussion Anthology (London, 1975). Other strict systems pieces occur in Christopher Hobbs: Duo Percussion Pieces, 1973-75 (Published privately by the composer, 1983; 2nd edition, Leicester, 2000).

${ }^{56}$ Brian Dennis, 'Repetitive and Systemic Music', p. 1038.

${ }^{57}$ Christopher Hobbs, On the Musical Compositions of Christopher Hobbs (PhD thesis, De Montfort University, 2001), p. 13.
} 
12,13 , and so on to 20,20 , etc.) indicate the interval of numbers of units between each block or cymbal entry (these units translated into quaver lengths in the performance score). The numbers under the initiation of each four-note block or cymbal entry is the interval between each note.
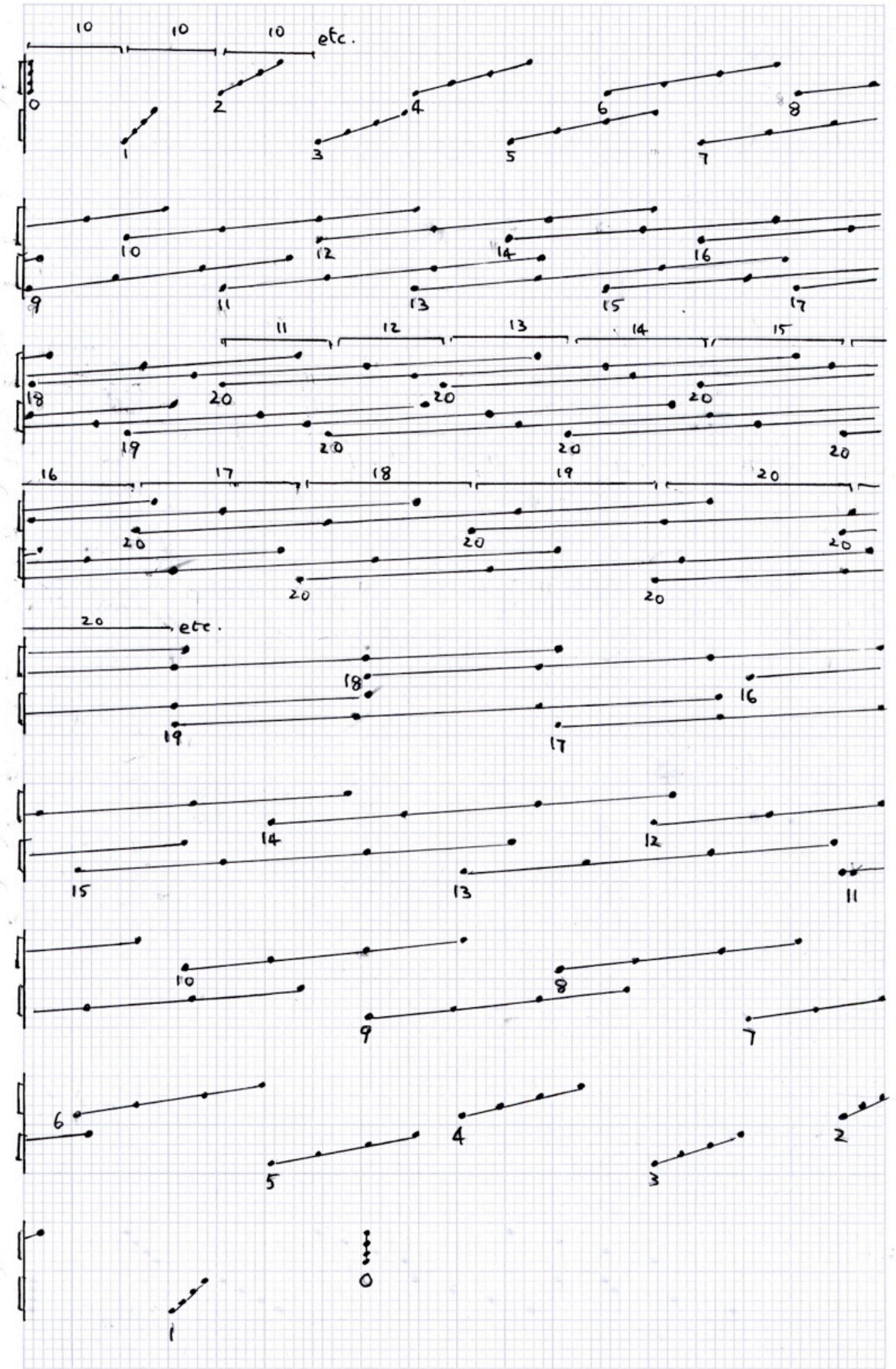

Fig. 4.1 Christopher Hobbs, Number Piece 1 (1973), graphic representation 
The system begins with, first, all blocks together, followed ten units later by all cymbals played one unit apart, then ten units later, the four blocks are played at two unit intervals. These entries begin every ten units, increasing their distance (cymbals by three units, blocks by four, and so on), as noted under the beginning of each entry. Because these increases in delay begin to overrun the ten-unit entry interval (from the block units marked ' 4 ' on the first system), the counterpoint becomes increasingly complex. When the blocks reach a point where each of the four notes are separated by a rest of twenty units (at the first block entry on system three), the following cymbal entry comes eleven units later, then twelve to the following block entry, and so on (shown in the brackets above the third, fourth, and fifth systems), until the second cymbal entry of system four, which occurs twenty units after the previous block entry. From this point until the end, the entrances remain twenty units apart. After the second twenty-unit initiation (in the fifth system, under Hobbs's 'etc.'), the interval between each note of the four-note entries lessens, first to nineteen in the cymbals, to eighteen in the blocks, and so on, until the unison occurs in the final block entry. Thus there are two systemic processes: the interval within each four-note entry (its perceived tempo) and the interval between one four-note entry and another (a kind of hypermetre, although one that is mostly hidden). The tempo process is palindromic, beginning and ending with the blocks in unison; the hypermetric process is directional, moving from ten to twenty units and then remaining thus for the duration of the piece.

In the final performing edition, the notation reveals some aspects of the system, but it obscures others. Hobbs used a $5 / 4$ time signature to accommodate the ten-unit (quaver) onset intervals at the beginning; thus the first twenty-one bars begin the first twenty-one entries, making the system easier to follow (see Ex. 4.2).
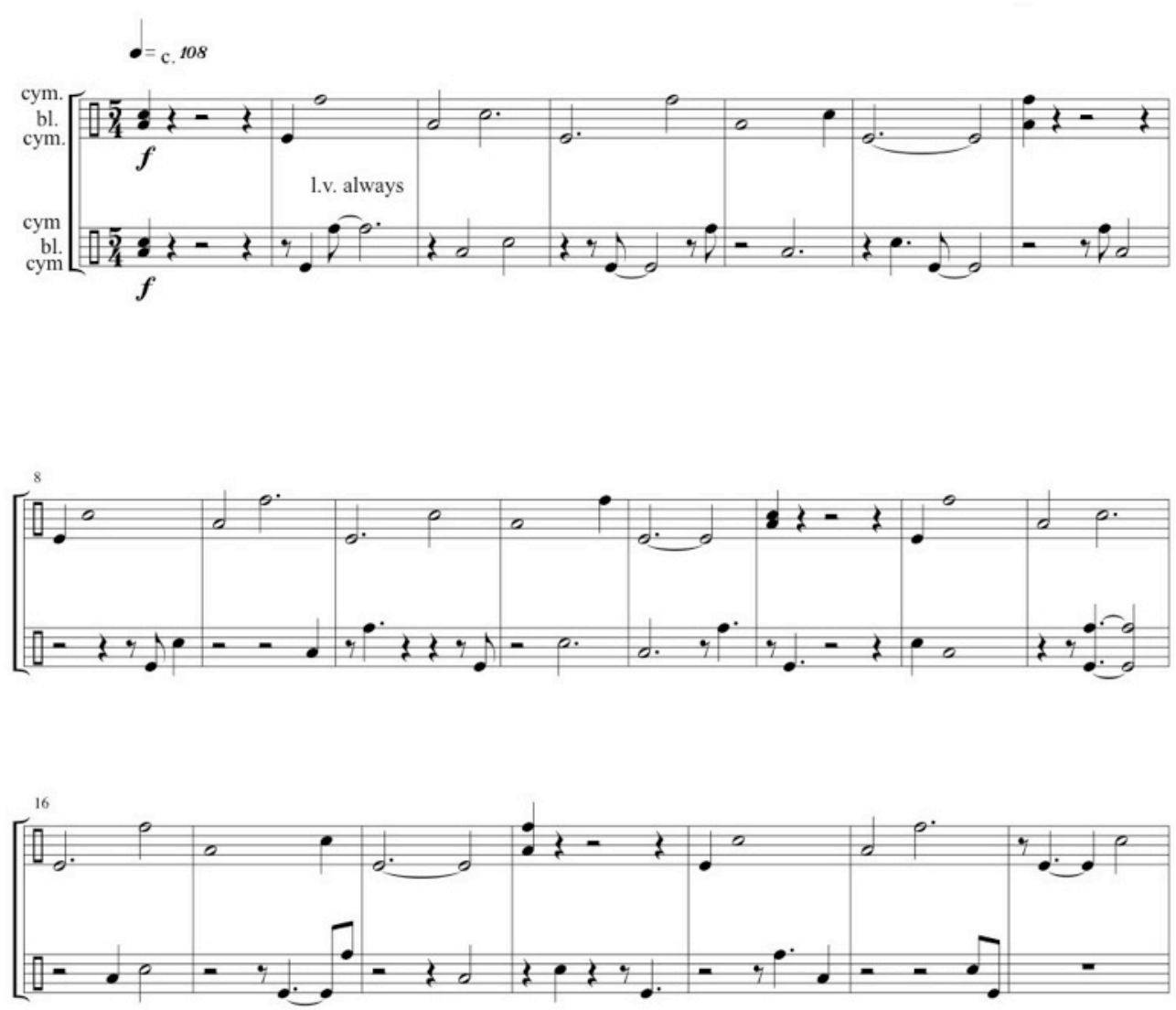

Ex. 4.2: Christopher Hobbs, Number Piece 1, score, bb. 1-22 
The performing edition also obscures the alternation between the instruments, as the blocks and cymbals are divided between the two performers. The division of the parts no longer appears in a linear fashion, with blocks on one staff and cymbals on another, but rather in two blocks and two cymbals on each staff. This results in a sound diffusion that is different from, say, Klangfarbenmelodie, in that the players divide the block and cymbal timbre as well as the 'melody'. Hobbs extends durations within each entry and beams items in different groups, indications that are not part of the system. As blocks have a quick decay and cymbals, marked 'l.v.' (laissez, vibrer), have an extremely long one, these notated durations have no correlation either with the system or with the resultant sound. These are performance aids only, to give each player the illusion of horizontal linearity.

White's percussion music for the Hobbs-White Duo uses similar durational processes applied to these instruments. In a similar system, Parsons contrasts 36- and 48-beat phrases in the first of his Six Pieces in Counterrbythms for two drummers (1974)..$^{58}$ In his 1976 article, Parsons also shows that systems processes were applied to pitch elements in Skempton's Slow Waltz for piano three hands (1973), the second piece of what must be Smith's 10 Pieces for 2 Baritone Horns (1975), and his own Levels for piano solo (1976). These pieces using pitch systems satisfy Hobbs's definition of systemic processes as 'dictated by a numerically expressible construct', but they do so with varying degrees of personal expression. They do not resemble the 'cool' linearity of systems art as much as the percussion pieces do. It is therefore harder to discriminate between these 'systemic' pieces and freely written or random machines and other minimalism.

\section{After strict systems}

John White and Christopher Hobbs soon moved from pure percussion music to, as Michael Parsons described it, 'a more empirical kind of composition which draws upon a wide range of reference to musical styles of the past'. ${ }^{59}$ For Parsons, this change in style (better described as 'eclectic' than 'empirical') was not only a move from systems, but also from experimental music:

Their loss of interest in systemic music arises from a feeling that it is too circumscribed for their present needs, and that empirical writing offers more opportunity for dramatic expression, and a chance to make meaningful reference to a variety of different styles. Their teaching work at the 'Method'-based Drama Centre may have influenced this change of interest: the detached and demonstrative techniques of experimental music may be seen as having more in common with Brechtian principles..$^{60}$

However, their change could also be seen as a welcome return to referential music. Bryars considered reference to be important to their work:

What John and Chris and others were doing was nearly always referential. There was always some outside reference to other music: to Elizabethan music or piobaireachd or something. They were playing games with musical structures and reworking them. It was not just some sort of [Bryars sings a parody of quaver-based process music]; it would actually come from somewhere else and have a different resonance, which for me always gave it greater depth. ${ }^{61}$

One of the oddest features of British experimental music history is that in less than a decade its practitioners moved from indeterminacy and chance to numerical processes as

\footnotetext{
${ }^{58}$ Parsons, 'Systems in Art and Music', p. 817.

${ }^{59}$ Ibid., p. 816.

${ }^{60}$ Ibid., p. 816.

${ }^{61}$ Gavin Bryars, interview with the author, 8 September 2011.
} 
limiting as total serialism and then to freely composed tonal music. These composers seemed to distrust systems for a number of years (with the possible exception of Parsons, who defined his use of these processes as 'experimental'), until the early 1980s, when digital electronic instruments gave them an outlet for systemic processes.

While Parsons and Skempton wrote much the same proportion of free and systems processes as they had done before, and Bryars moved to opera and larger commissions, from 1974 to 1976 the Hobbs-White Duo wrote and performed pieces for piano duet and other instruments using an extended tonal language. After 1976, White worked with Bryars, Smith, and Ben Mason (b. 1953) in the Garden Furniture Music Ensemble, among others, creating and performing Satiean pieces of great charm and humour. Steele notes that White's primary interest in music of the past (for instance, he claims a debt to Domenico Scarlatti for his piano sonatas) displays a fundamental difference between visual arts and music as disciplines: "while composers (such as John White) may openly acknowledge the technical derivation of their forms, the term "derivative" in contemporary art criticism comes perilously close to denoting plagiarism'. ${ }^{62}$ Hobbs's post-systems music in the 1970s includes an operetta, The Mountebanks (1976, libretto by W. S. Gilbert) and other music for theatre, solo piano music, and a number of commissions for groups in California. ${ }^{63}$

Other British minimalist composers achieved success in the 1980s, but they tended to be closely dependent on the language of the American process minimalists, Louis Andriessen, or Alvin Lucier. In contrast, the systems composers continued a unique and separate tradition. In the early 1980s, the availability of domestic digital electronic keyboards allowed White, Hobbs, and, for a while, Mason, to use systems processes to generate electronic music of a delightfully quirky humour. In particular, White's electronic systems in his 'electric' symphonies and shorter occasional pieces are leavened with the full range of sounds available on the equipment, including animal noises, special effects, and 'oops' stops. More recently Hobbs has used 16 x 16 'mega' Sudoku puzzles to generate electronic systems. ${ }^{64}$ These later systems by both composers are at the same time strict and jolly, and even, quite often, hilarious.

\section{Conclusion}

Perhaps the strict systems of the mid-1970s could not be sustained for long. It seems ironic that after embracing indeterminacy and shunning the serialist processes of the European avant-garde, these composers should take up compositional methods that were equally limiting. Although some neo-constructivist work uses chance procedures Kenneth Martin's work in the 1950s and after was directly influenced by Cage and George Brecht ${ }^{65}$ — the strictures and rigour of systems art seem to have more in common with various types of music complexity, serialism or post-serialism: more comfortable for composers, such as Pierre Boulez, in the avant-garde opposition. Before strict systems music began, Nyman accused the avant garde of marching 'along the well-

\footnotetext{
${ }^{62}$ Jeffrey Steele, 'Chance, Change, Choice, and Order: A Structural Analysis of a Work by Kenneth Martin', Leonardo, 24/4 (1991), p. 408.

${ }^{63}$ Although the association between Bryars and the Southern Californian composer Harold Budd is known, the influence of British experimentalists (Hobbs and Skempton in particular) on other Southern Californian composers needs further study.

${ }^{64}$ Hobbs's rotational variants of these puzzles recall not only Steele's systems art, but also parallel Paul A. Epstein's durational systems based on work by the artist Sol LeWitt.

${ }^{65}$ Jeffrey Steele, 'Chance, Change, Choice, and Order', p. 409.
} 
trodden and sanctified path of post-Renaissance tradition'. ${ }^{66}$ After the decline of strict systemic musical processes, Nyman distanced himself from systems, declaring his work to have more in common with Baroque ground repetition, 'while systems music in general is related, however distantly, to serialism'. ${ }^{67}$ Keith Potter noted that Michael Parsons had 'a serial pedigree', ${ }^{68}$ but for the other composers mentioned here, the allegation of being a serialist would almost be an insult.

These concerns emphasise the primacy of the system over the thought that it articulates, which is the wrong way round. For all their writing about indeterminacy, notation, and other technical features, experimental musicians have always privileged thought over process. That La Monte Young and Steve Reich used serial methods in their early pieces does not tie either composer to the great serial tradition, because they did not use it in the way that Arnold Schoenberg, Anton Webern, Milton Babbitt and Boulez used it. Young saw stasis in Webern; ${ }^{69}$ Reich seems to have used a serial row as a kind of ground for repetition. ${ }^{70}$ Similarly, British systems composers 'play games with musical structures', as Bryars notes. ${ }^{71}$ They use references, but they do not develop them as argument or expression. White, in particular, neutralised any sign of great-art pretension with a Satiean musical instruction or comic sound. To a variable extent, this neutral, but playful, approach applies to all of these composers. The British minimalists found Reich's Four Organs familiar because they understood it as a structural game. It is this idea of 'play' that has remained constant among British minimalists, despite their radical shifts in sound and system.

\footnotetext{
${ }^{66}$ Michael Nyman, Experimental Music, p. 2.

${ }^{67}$ Michael Nyman, 'Against Intellectual Complexity in Music', October 13 (1980), p. 83.

${ }^{68}$ Keith Potter, Four Musical Minimalists: La Monte Young, Terry Riley, Steve Reich, Philip Glass (Cambridge, 2002), p. 11.

${ }^{69}$ Nyman, 'Against Intellectual Complexity', p. 84. La Monte Young quoted from Richard Kostelanetz, 'Conversation with La Monte Young', in La Monte Young and Marian Zazeela, Selected Writings (Munich: Heiner Friedrich, 1969), p. 24.

${ }^{70}$ Potter, Four Musical Minimalists, p. 157.

${ }^{71}$ Gavin Bryars, interview with the author, 8 September 2011.
} 